\title{
OPTIMIZING DISPERSED AIR OPERATIONS: A CONCEPT TO USE HIGHWAYS AS IMPROVISED AIRFIELDS IN A CONTESTED ENVIRONMENT
}

\author{
by \\ Benjamin B. Hatch, Lt Col, USAF \\ A Research Report Submitted to the Faculty \\ In Partial Fulfillment of the Graduation Requirements for the Degree of

\section{MASTER OF OPERATIONAL ARTS AND SCIENCES} \\ Advisor: CDR James K. Selkirk, USN \\ Maxwell Air Force Base, Alabama
}

April 2015 
AU/ACSC/HATCH, B/AY15

\section{DISCLAIMER}

The views expressed in this academic research paper are those of the author and do not reflect the official policy or position of the US government, the Department of Defense, or Air University. In accordance with Air Force Instruction 51-303, it is not copyrighted, but is the property of the United States government. 


\begin{abstract}
The US Air Force stages fighter and other aircraft at main operating bases at central locations across the globe to gain efficiencies in operations, maintenance, and security. However, these bases are lucrative targets, and adversary missile development continues to place air operations from main operating bases at risk. In addition to security concerns, examples in air operations since World War Two illustrate how sustaining sortie generation from main operating bases to locations over extended distance presents operational risk due to the amount of flying time required from takeoff to landing, as well as the potential for pilot fatigue in sustained conflict. An alternative to main operating bases is to disperse air operations, which affords certain advantages; however, the Air Force has limited capability to conduct airfield surveys outside of a permissive environment. Optimizing the Rapid Raptor Forward Arming and Refueling Point (FARP) concept to include suitable highways and other roads is necessary to avoid a scenario limited by operating from established civilian airbases, locations well known to the enemy. If the enemy can find US aircraft, those platforms are inside the enemy's kill chain. Conversely, dispersed FARP sites using suitable highways and other roads disrupts the enemy's kill chain as the enemy is unaware where air operations are generated. Investments in a low cost multipurpose remotely operated vehicle, outfitted with scientific and other instruments capable of conducting surveys and assessments of potential improvised FARPs, solves the current capability challenge of conducting site surveys outside of permissive environments. It also offers multiple advantages to a US air strategy of dispersing airfield operations in a contested environment. The ability to conduct air operations closer to a potential adversary or humanitarian situation, while complicating an adversary's ability to find and target one's own aircraft during a conflict, is a critical enabler in the ability to project power by 2040 .
\end{abstract}




\section{Contents}

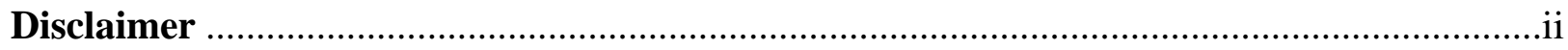

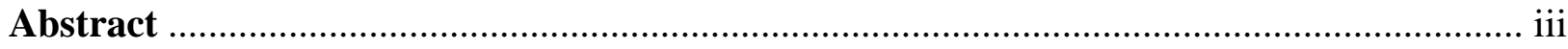

Introduction: A Glimpse Into the Future .......................................................... [1]

An Overview of the Strategic Problem .................................................................. [3]

An Overview of the Operational Challenges ............................................................... [6]

The Strategic Importance of Dispersed Airfields ................................................. [9]

An Initial Approach at Dispersing Air Operations: Rapid Raptor Concept ................. [12]

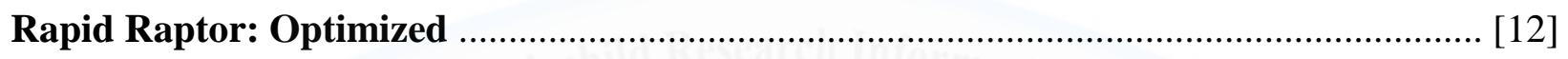

A Review of Air Force Airfield Survey and Assessment Capabilities ........................... [16]

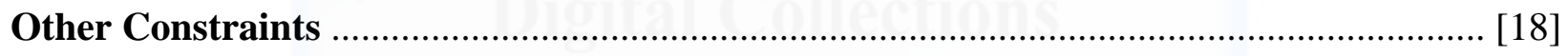

Opportunities for Technological Investment ....................................................... [19]

Evaluating the Potential of Asian Highways as Improvised Dispersal Airfields ............ [23]

Humanitarian Power Projection in Highly-Contested Environments .......................... [25]

Opportunities for Deception Operations ............................................................... [27]

Summary and Conclusions ........................................................................ [28]

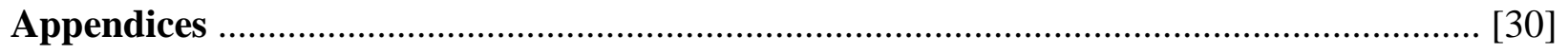

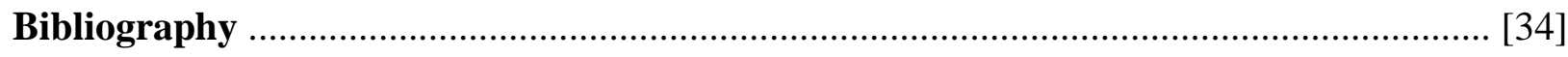




\section{Illustrations}

Figure 1: Chinese Missile Capability..................................................................... [5]

Figure 2: A Belarus MiG-29 takes-off from a long stretch of highway.............................. [11]

Figure 3: A Swedish Fighter at an Austere Dispersal Location ....................................... [11]

Figure 4: A Taiwanese F-16 Lands on a Highway during Exercise "Han Kuang” ................ [11]

Figure 5: China's Conventional Strike Capability ................................................... [14]

Figure 6: Airfield Evaluation Procedures ............................................................. [16]

Figure 7: NASA Mars Rover Curiosity ................................................................ [20]

Figure 8: NASA designed the Curiosity to be air deliverable and transportable ................... [21] 
AU/ACSC/HATCH, B/AY15

\section{Tables}

Table 1: Summary of Asian Highway Design Standards 


\section{Introduction: A Glimpse Into the Future}

The year is 2037. The threat to American and allied air and space forces is high, while movement and maneuver in areas beyond the global commons is contested. As regional tensions mount, the top commander of Pacific Air Forces (COMPACAF) receives an urgent message from her Air Force Office of Special Investigations (AFOSI) representative. The information provided outlines specific details from a well-placed AFOSI informant that missile launches targeting Anderson Air Force Base, Guam, and other US bases in the Pacific are imminent. ${ }^{1}$ Understanding that the adversary's war plan includes first strike missile launches against established United States (US), coalition, and many civilian airfields, COMPACAF orders flushing aircraft from the main operating bases and to stage operations at dispersed locations throughout the Pacific.

Upon receipt of the order, an Air Force noncommissioned officer reports to a hardened ground control station (GCS) capable of surviving a direct hit from nuclear munitions. Once there, he launches a swarm of relatively small and inexpensive, yet highly specialized remotely piloted vehicles (RPV). The specialized RPVs, known as Remote Surface Survey Assessment Vehicles (RSSAV), are equipped with sensors and scientific instruments to find, survey, and assess locations for dispersed manned fighter, cargo, and drone aircraft take-offs and landings. At the dispersed locations, the necessary rearming, refueling, and maintenance of the fighter, cargo, or drone aircraft can take place. A proven multipurpose platform, the RSSAV's various scientific instruments were used across the globe throughout the previous decade building cultural ties by conducting soil testing and evaluation as part of agricultural management efforts during regional stability operations and humanitarian crises. The RSSAV can transition from humanitarian operations to a combat application by operating a switch. 
Meanwhile, a networked space sensor sends information to a GCS outlining multiple paved highways and roads that intelligence analysts identified as meeting the minimum length and width requirements for aircraft operations. The RSSAVs automatically adjust their flight paths to the identified potential dispersal airfields. Once over the potential dispersal airfield, a RSSAV conducts low-level flights and uses a high-definition camera to search for obstructions along the road. Other RSSAVs land to provide security and establish road blocks. After determining the road is clear of hazards, the RSSAV takes precise measurements of the length and width of the road. The section of road identified is more than 8000 feet $(\mathrm{ft})$ long and in excess of $75 \mathrm{ft}$ width, which is within the runway minimums required for most fighter aircraft. ${ }^{2}$ If there is minor damage to the road, the RSSAV repairs it by dispensing a quick drying epoxyresin material. For extensive damage to the road, the RSSAV prints airfield-grade matting tiles using a 3D printer.

On the ground, the RSSAV conducts a series of field tests to further assess if the location is suitable for air operations. ${ }^{3}$ One scientific instrument, the Electronic Cone Penetrometer, hydraulically penetrates through the concrete or asphalt, as well as the underlying soil layers 5 to $7 \mathrm{ft}$ into the earth. A data-linked computer measures the cone tip and sleeve pressure readings, and the information obtained is correlated to California Bearing Ratio value to determine the empirical measure of soil strength. Another scientific instrument tests the earth to classify the soil type and consistency of the various layers.

After performing tests at the specified points along the road and clearing the area of foreign object debris, the RSSAV signals the location is suitable for dispersed airfield operations. The RSSAV remains on the ground as acts as an air traffic control beacon and navigational aid to alert the inbound fighters where to land. As the missiles strike Anderson AFB, and other Pacific 
bases, COMPACAF prepares to execute the air tasking order with America's fleet of aircraft that survived the missile attack safely away from the main operating base at the dispersed locations.

The introductory story illustrates that the ability to conduct air operations away from main operating bases and at dispersed locations will be a critical enabler in the Air Force's ability to project power by 2040 . In doing so, US forces will be able to operate closer to the areas near a potential adversary or humanitarian situation. Furthermore, dispersed operations complicates an adversary's ability to find and target US aircraft, which promotes increased survivability in a highly contested environment. As such, this paper argues that investments in a multipurpose remotely operated vehicle, outfitted with scientific and other instruments, which can conduct assessments and survey potential improvised Forward Arming and Refueling Points (FARP), would present multiple advantages to a US air strategy of dispersing airfield operations and aircraft staging in a contested environment. It is along this thread that this paper will discuss an overview of the strategic problems air planners encounter when evaluating ways to project power in highly contested environments, as well as discuss operational challenges concerning air operations over extended distances from main staging bases outside the probable mission area.

\section{An Overview of the Strategic Problem}

In looking forward to the potential realities the US military will encounter by the year 2040, one variable is viewed as a certainty - the US will enter a period of increased constraints on US military actions abroad. Compounding that reality is US military power will continue to compete in shared environments that are evolving and more-complicated as additional nations and nation-states across the globe develop their own advanced military capabilities, and at times, 
engage in provocative behaviors. These shared spaces are in all domains, to include space, air, cyber, and the sea.

According to The Joint Operational Access Concept (JOAC), the essential access challenge for the future is to be able to project military force and power into an operational area and sustain it in the "face of armed opposition by increasingly capable enemies when US overseas defense posture is changing and space and cyberspace are becoming increasingly important and contested domains." Consequently, the JOAC argues, as competition increases, the US military will likely be required to stage and operate, not from forward areas close to the front lines of the operating location, but rather further from the problem and within the global commons areas.

In the Pacific, China, for example, has been rapidly modernizing its military. ${ }^{5}$ Investments include weapons and other programs intended to improve extended-range power projection capabilities, to include developments in space, cyberspace, and electronic warfare. ${ }^{6}$ Short and long range missiles and submarines are the two main thrusts of the modernization aimed at denying access to regional sea and aerial lines of communication. The Pentagon referred to China's investments as creating "the most active land-based ballistic- and cruisemissile [program] in the world."7 Consequently, the outward trend in China's weapons production facilitates their desired military capabilities to the real potential of military operations throughout the region, well beyond China's traditional territorial claims. The developments are not surprising, as Chinese military spending has grown annually at a rate of 12 percent. Sustained defense budget spending rates will rival that of the US by $2035 .{ }^{8}$ At this rate, the Chinese missile inventory will likely surpass America's ability to provide sufficient missile 
defense. The below 2010 chart outlines Chinese missile capabilities, and illustrates the threat to US main operating bases.

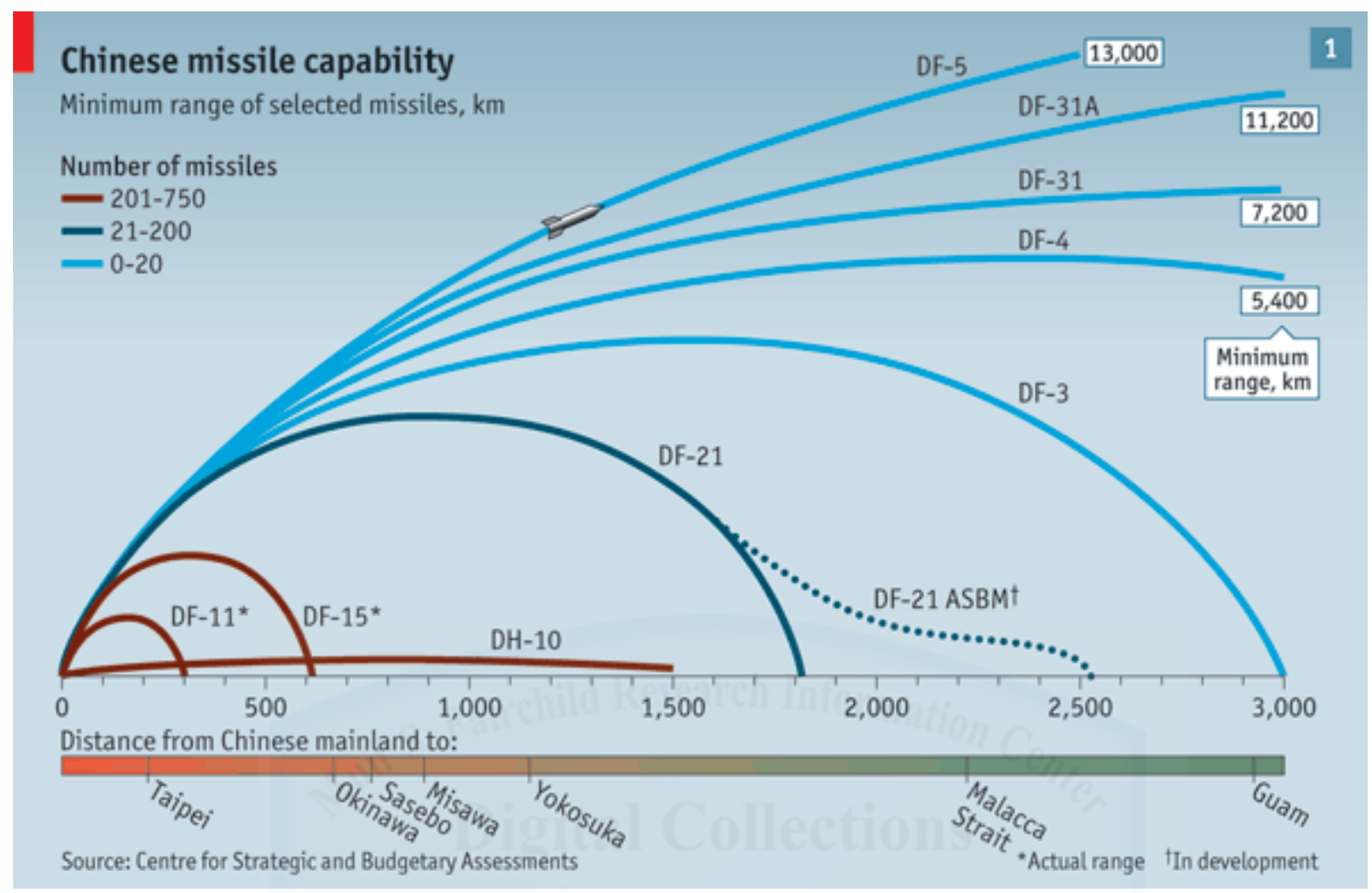

Figure 1: Chinese Missile Capability ${ }^{9}$

In a historical context, a strategy of relocating aircraft out of the range of an adversary was successful for the English during the Battle of Britain in countering the limited range of the Luftwaffe. While this approach enabled a defensive victory for the Royal Air Force during World War Two, modern day advancements in air refueling and the extended range of precision missiles place "rearward" basing at risk. ${ }^{10}$ As such, the ability to extend the distance from the likely mission area in order to project power from range is also being highly challenged. 


\section{An Overview of the Operational Challenges}

Power projection in the future will not resemble the operational construct of 2015.

Currently, air operations in the permissive threat environments over Iraq and Afghanistan have benefited from the Air Force being able to forward deploy and base fighters at main operating bases within close proximity to the fight. Conversely, contested threat environments, such as the

Anti-Access/Area Denial (A2/AD) systems currently being developed and employed by potential future adversaries, such as the Chinese, challenge the Air Forces' ability to project power from forward deployed airfields in the Pacific. While staging fighter aircraft at a main operating base offers certain efficiencies in maintenance and security, these bases also become lucrative targets. In fact, China's Joint Anti-Air Raid Campaign centers on fielding capabilities and operations to attack adversary airbases and aircraft carriers. ${ }^{11}$ Massing air forces at one location comes with operational and security risks if the main operating base is attacked.

Alternatively, power projection from distant bases present additional challenges. According to a 1999 RAND study, USAF combat aircraft probably could not sustain intense combat operations, defined as one sortie per day per aircraft, over a distance of more than about 2,000 nautical miles (nmi), even if supported with air refueling. RAND also found that aircraft cruising at 500 knots would require approximately eight hours to complete a 2,000-nmi mission. RAND concluded missions over such as distance would take too much time to meet the requirements for sustained combat operations. Further, RAND determined that fighter aircraft and crews would likely experience fatigue after conducting these extremely lengthy missions. ${ }^{12}$

Prior US combat air operations outline examples of the time involved to conduct air strike operations from distant main operating bases. During the opening strikes of Operation IRAQI FREEDOM, B-2 stealth bombers launched from Whiteman AFB, MO, endured 15 hours 
of flight time to reach the target area over Iraq. ${ }^{13}$ In a mission over Afghanistan, one B-2 sortie required 44.3 hours from takeoff to landing. Fighter aircraft supporting Operation ENDURING FREEDOM would commonly endure ten hour or longer missions, extending the time over an area of operations with the aid of tanker refueling. Naval aircraft experienced similar challenges dealing with the "tyranny of distance," where carrier-based strike operations over Afghanistan were the "longest range" flights conducted in the history of naval air warfare. ${ }^{14}$ According to airpower author Benjamin Lambeth, the main limiting factor in air operations over Afghanistan was people rather than equipment. ${ }^{15}$

In the Pacific, air strikes during the Vietnam War from Andersen Airbase, Guam, to Hanoi, North Vietnam, required a pilot to fly nearly three thousand miles and encapsulated eight hours of flight time. ${ }^{16}$ The previously referenced RAND study findings, as well as recent examples highlights that while US pilots are capable of boldly and bravely conducting air operations over distance, there is risk of fatigue over time. Further, the ability to sustain sortie generation from main operating bases to locations over extended distance presents certain operational risk due to the amount of flying time required from takeoff to landing.

Main operating bases for US air operations are priority targets for potential adversaries and will be at risk of attacks that will disrupt sortie generation. According to author Christopher Centner, war planners for Operation DESERT STORM included options to target and render inoperable all of Iraq's suitable airbases. ${ }^{17}$ Centner further stated planners set criteria to evaluate if a particular airbase was sufficiently damaged or destroyed post-attack to assess if additional attacks were prudent. This information was used to determine sortie requirements for strike packages built into the air tasking order. While targeting each of the 66 established Iraqi airbases were later prioritized to those airbases assessed to having links to the strategic goal of 
liberating Kuwait, the initial plan to target each airbase highlights the potential vulnerability of main operating bases as airbases are seen as key nodes to achieving air superiority of an operational area during the planning process.

A strategy of targeting airbases was also part of the air planning for Operation IRAQI FREEDOM. According to Lambeth, Air Forces Central Command planners assessed there were sufficient assets available each day to conduct attacks against approximately 1,000 Iraqi targets. Of the potential targets, General Moseley's planning team included 350 airfields as a priority in the establishment of theater air superiority. ${ }^{18}$ On March 21, 2003, coalition forces dropped precision munitions on all major Iraqi airfields, cratering the runways and taxiways, which rendered the sites unusable. ${ }^{19}$

Conducting air operations from main operating bases increases the probability of early warning and detection of aircraft departures. In the Pacific, China's improved Command, Control, Computers, Communications and Intelligence, Surveillance and Reconnaissance (C4ISR) network, including space-based and over-the-horizon sensors, will enable their military to identify, find, track, and target US military activities at extended ranges across the western Pacific Ocean. Even if the final target remains unknown to the Chinese mission planners, once the C4ISR network is capable of tracking US activity from main operating bases, those activities will assume certain risk.

Of note, historical examples involving US air operations highlight the dangers of early warning of aircraft departures from main operating bases. On December 18, 1972, at the onset of the Linebacker II bombing campaign during the Vietnam War, the North Vietnamese General Staff received a message that "many squadrons of B-52 planes have taken off from Andersen Airport." One half hour later Hanoi's air defense network went on alert, while six MiG-21 
aircraft at three nearby bases were placed on a 7 minute response alert. ${ }^{20}$ The B-52 strike package subsequently flew into an air defense network ready to shoot them down.

A key takeaway from these examples is an understanding and acknowledgement that US air operations are studied, and many times copied or incorporated in adversary war planning. As such, if the US builds campaign plans to attack and render ineffective established airfields, it is likely adversaries and potential adversaries have similar plans to attack established airfields.

An operational concept to project power while enabling and sustaining freedom of movement outside the current main operating base construct is through dispersal of air operation locations. Consistent with Admiral Charles Turner Joy's rule of war, "We cannot expect the enemy to oblige by planning his wars to suit our weapons; we must plan our weapons to fight war where, when, and how the enemy chooses."21 Consequently, dispersing small numbers of fighter aircraft to various expeditionary or improvised airfields can mitigate some risk associated with staging numerous aircraft at a main operating base. Further, this concept would complicate Chinese targeting of airpower capabilities, reduce pilot fatigue, and improve fighter survivability.

\section{The Strategic Importance of Dispersed Airfields}

Early airpower theorists, to include Italian Gen Douhet, recognized the strategic value and risk associated with staging large quantities of airplanes at main operating bases. "It is easier and more effective," Douhet argued, “to destroy the enemy's aerial power by destroying his nests and eggs on the ground than to hunt his flying birds in the air."22 Originally published in 1921, his metaphor highlights the extreme vulnerability of aircraft on the ground.

Unfortunately, there are multiple examples where air planners did not heed Douhet's warning. Most notably, the Japanese surprise attack against Pearl Harbor and other US military 
sites on December 7, 1941, resulted in 188 of 394 aircraft destroyed, and another 159 damaged. ${ }^{23}$ Alternatively, the Japanese were unable to target the dispersed Navy carrier fleet.

Conflicts between Arab nations and Israel further highlight the strategic and decisive importance of airfields. During the 1967 Six-Day War, Israel conducted a surprise attack against Arab air forces parked at their main operating bases. Of note, Arab aircraft were positioned wingtip-to-wingtip and exposed outside any hardened shelters at the airfields. Caught by surprise, Israel destroyed 375 Arab aircraft on the ground during the first day of the war at a cost of 19 Israeli aircraft lost. ${ }^{24}$ With control of the air, Israel successfully tilted the military advantage to their cause.

A dispersed air operation mitigates some risk of operating from main operating bases and complicates enemy targeting missions. In 1941, Lt Col Harold Lee George and a team of planners evaluated the vital links of the German war machine in an attempt to prioritize targets that would lead to Hitler's defeat. Discussions regarding the necessary steps to gain air superiority over Germany resulted in an evaluation of the Lutfwaffe and their operations. George and his planners concluded that attacking the German air bases individually would not be decisive, as the airbases were "well dispersed" and heavily defended. ${ }^{25}$ The inability to attack the dispersed airbases led the planners to target the Lutfwaffe while the airplanes were under construction and remained at the factories. The same was true for the oil products that fueled the German war machine. According to author Tami Davis Biddle, US and British air planners were unsuccessful in their attempts to target oil as the path to reach a key German weakness as the Germans were "likely to disperse their oil production or to find substitutes for it." 26 Author Robert Pape argued that "opponents can reduce the effects" of targeting military strength through dispersing important items and materials. ${ }^{27}$ 
Technological advances have increased an adversary's ability to target multiple airbases over distance. As such, modern Air Forces, such as Taiwan, Sweden, and Belarus, employ dispersed tactics for air operations. ${ }^{28}$ Of note, these countries have launched and recovered third and fourth generation aircraft, to include F-16s, MiG-29s, and Su-25s from highways. For example, the Taiwanese Air Force annually practices take-offs and landings from improvised sections of a highway during Exercise "Han Kuang." 29 Ground crews also practice rearming munitions and refueling at these dispersed locations.

According to J. Michael Cole, the Taiwanese Government understands that the first phase of a Chinese missile attack would target Taiwan's air bases, so alternates are necessary. ${ }^{30}$ While acknowledging that dispersed air operations would be a major disruption to the standard business practices experienced today, countries such as Taiwan recognize that failure to consider and implement alternatives to air operations from main operating bases in highly contested environments comes with risk to aircraft survivability and sortie generation.

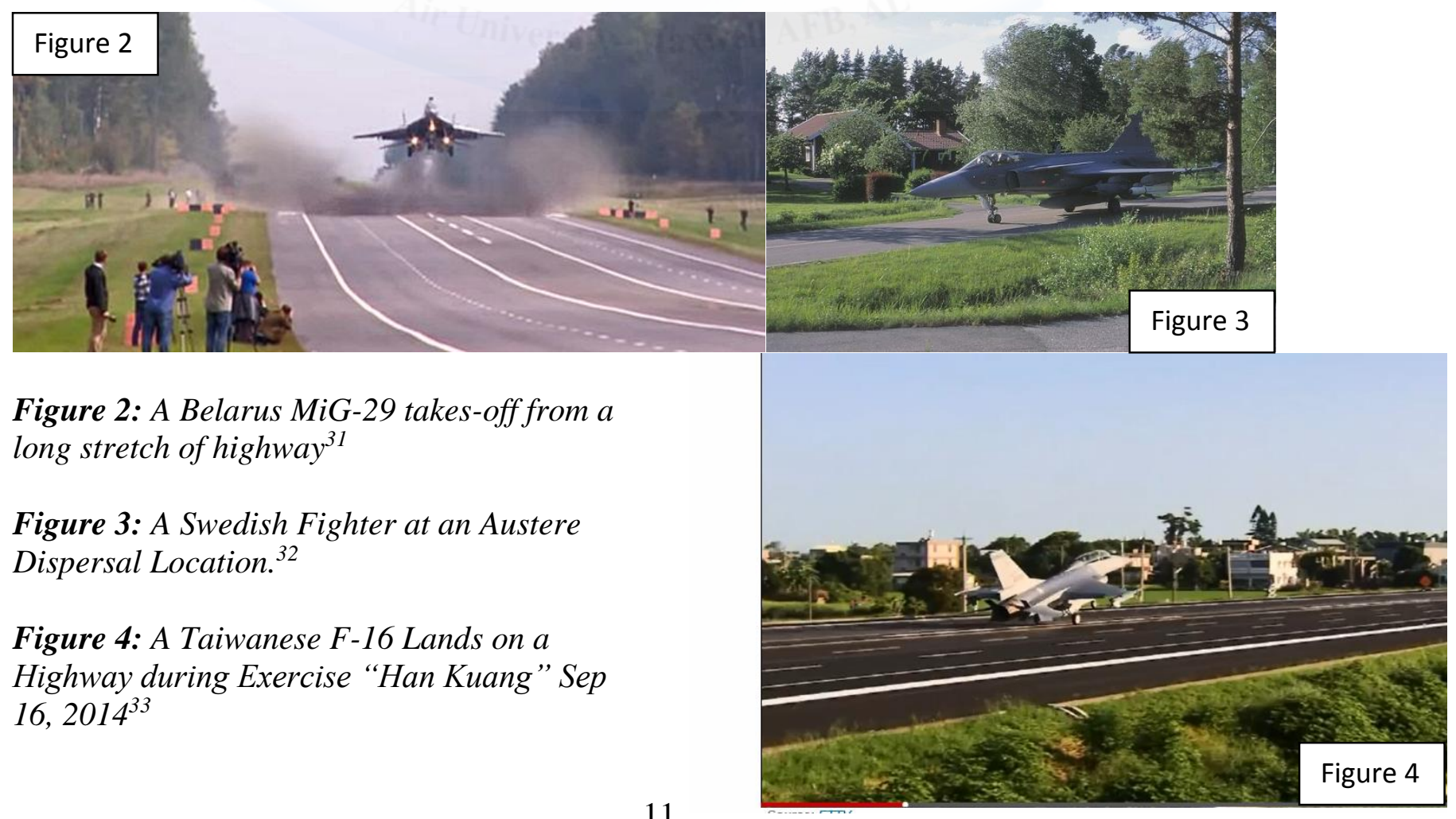




\section{An Initial Approach at Dispersing Air Operations: Rapid Raptor Concept}

The Air Force Rapid Raptor Fighter Forward Arming and Refueling (FARP) concept is an excellent first step in addressing a low cost solution to project power in a highly contested environment. The Rapid Raptor operational concept pairs F-22 aircraft with a C-17 mobility

platform to operate and maintain fighter operations forward of the main operating base. ${ }^{34}$ Using any suitable existing airfield across the globe, including civilian fields in austere environments, the $\mathrm{C}-17$ forward deploys maintenance personnel, munitions, and fuel to rearm, repair, and refuel F-22s for continued operations. ${ }^{35}$

In the Pacific, up to 258 civilian airfields may be suitable for fighter operations. ${ }^{36}$ As necessary, the $\mathrm{C}-17$ can also deliver rested F-22 aircrews to enable uninterrupted operations. A key element of the Rapid Raptor concept is the ability to overcome logistics challenges and maintenance requirements away from a main operating base, and successfully transport the requisite supplies to enable fighter refueling and rearming at a suitable FARP airfield. ${ }^{37}$ However, a fundamental limitation of the Rapid Raptor concept is its use of established airfields at civilian airports as the main criteria to be a viable fighter FARP location. This limitation is based on the assumption that if the US builds campaign plans to attack and render ineffective established airfields, which would include civilian airfields, it is likely adversaries and potential adversaries have similar plans.

\section{Rapid Raptor: Optimized}

The unpredictability of utilizing established civilian airfields for Rapid Raptor will provide substantial benefits in terms of operational flexibility and deterrent value for US 
planners. What complicates the situation, however, is that the Chinese and other potential adversaries are well aware of the 258 identified civilian airfields. As such, a course of action for China would be to preemptively target all the identified civilian airfields to deny US aircraft the opportunity to use them. However, even if China did not conduct preemptive strikes against the established civilian airfields, in classic kill chain speak, if an adversary can find US forces, or know where those forces may operate from, then those forces and the associated airfields are at risk of being targeted. ${ }^{38}$

Technology has increased the risk of operating from known locations. For example, technological advancements in an adversaries ISR processing, exploitation, and dissemination paired with global communications have reduced the sensor-to-shooter kill chain from days or hours to mere minutes. ${ }^{39}$ In that light, even if a potential adversary's war planners are unable to predict which established civilian airfield will be used for US air operations, the adversary may have sufficient early warning capacity near the established airfields, as well as the necessary time to intercept aircraft approaching one or more of the civilian airfields. Preexisting early warning capabilities, such as human informants living in cities near established civilian airfields, would also provide an enemy time to take military action to render the civilian airfields inoperable.

US Government analysts have confirmed the growing technical early warning capabilities of China. In a 2013 report to the US Congress, the Depart of Defense stated that China has developed a national integrated air defense system to protect mainland China, and analyzed that expansion of its national early warning network to protect territorial air, space, and waters farther from the mainland is probable. ${ }^{40}$ A worst case scenario is that US air planners incorrectly assume that these established civilian airfields will be available and serviceable for FARP 
operations. ${ }^{41}$ As such, this data highlights the requirement to develop an alternative plan for more unpredictable dispersed air operations.

Furthermore, it is commonly known that the Chinese and other potential adversaries are studious learners (and often copiers) of US operational planning. As seen during the air planning for the invasion of Iraq, targeting airfields and rendering them unusable is high on the preconflict priority targeting list. One can deduce, therefore, that the 258 identified civilian airfields in the Western Pacific Area of Operations would be targeted prior to, or during conflict ramp up, and become unserviceable through conventional or unconventional military operations. Figure 5. highlights the threat envelope of Chinese conventional missiles in the Pacific.

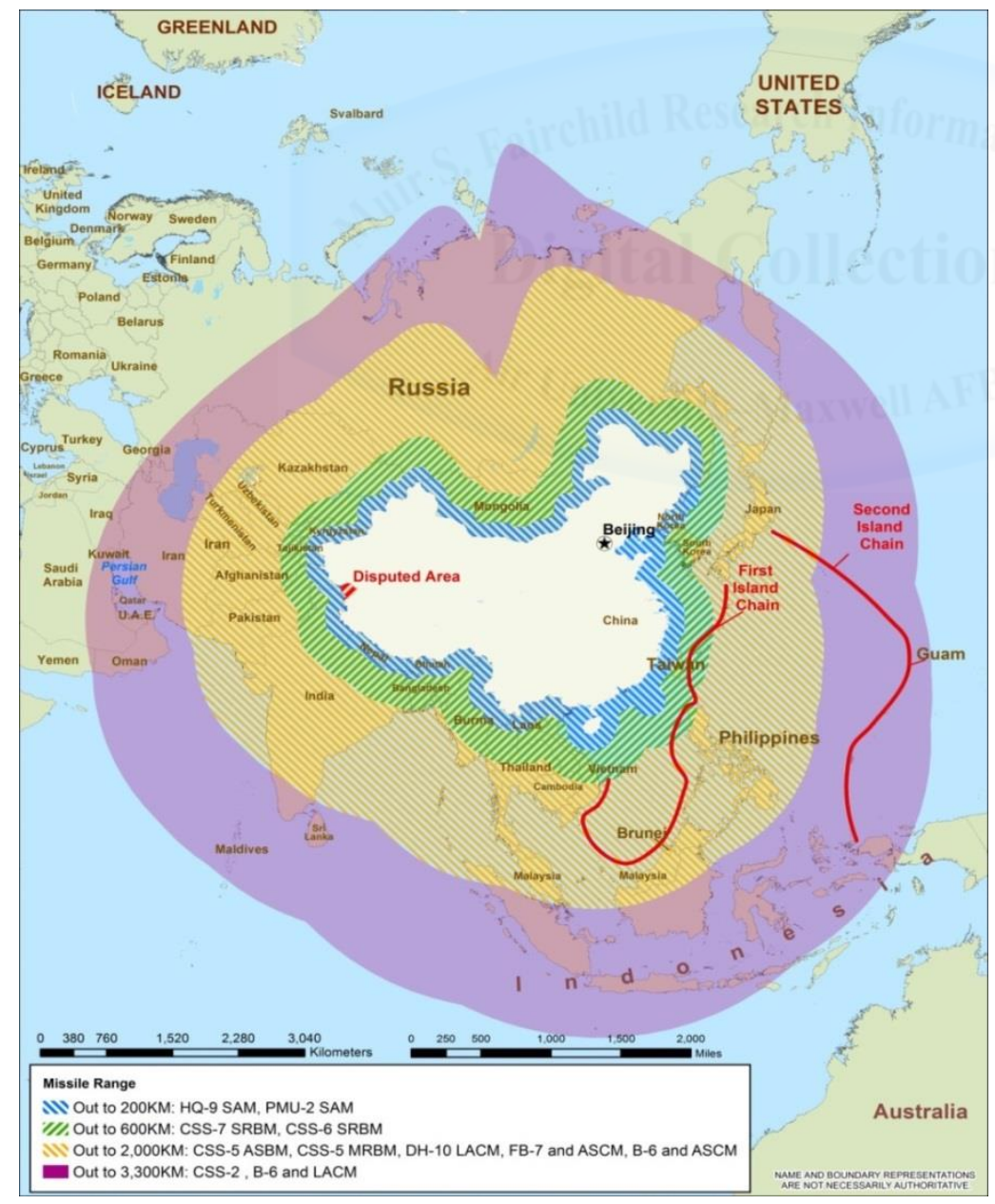

Figure 5: China's Conventional Strike Capability ${ }^{42}$ 
The Chinese have multiple arrows in their respective quivers in which to target and render US runways inoperable. Although cruise missiles or other standoff weapons are a primary focus of discussion as they may be launched to disable all or some of the civilian airfields, a more cost effective means to degrade the airfields would be through human saboteurs.

With only 258 civilian airfields, this low number of aim points would fit within estimates of the future quantity of Chinese missiles, and are a reasonably actionable number of missions for intelligence agents or special operations forces armed with explosive devices to crater portions of the runway. Potentially more frustrating is that an undetectable, and low cost solution, would be for the saboteurs to emerge from the civilian populous near the civilian airfields and break apart portions of the runway simply using a pick axe and a shovel. With a population over one billion, China has sufficient capacity to recruit an unsophisticated network of agents to conduct human intelligence reporting and to engage in saboteur operations if the need arises.

In order to further complicate the planning of Chinese and other potential adversaries, and improve US probability of locating and conducting air operations closer to the fight, the US must have a capability that enables air operations from more unpredictable locations. A network of remotely operated vehicles capable of conducting assessments of paved roads, or other nontraditional surfaces meeting the minimum requirements for air operations would increase the probability of successful refueling and rearming in a highly contested environment. If the US can shorten the distance and flight time associated with air operations conducted from main operating bases through refitting, refueling, and rearming at improvised locations closer to the fight, and those locations remain unknown to a potential adversary, the strategic value of an operational concept such as Rapid Raptor can be optimized. In order to determine the 
requirements necessary to optimize this promising operational concept, it is first necessary to review the process by which the Air Force conducts surveys and assessments of airfields.

\section{A Review of Air Force Airfield Survey and Assessment Capabilities}

The US Air Force's airfield survey and assessment capability is currently sized, equipped, and trained to operate in permissive environments. ${ }^{43}$ The HQ Air Force Civil Engineering Support Agency Pavement Evaluation Team is assigned as the primary office with the responsibility to assess the structural capability of airfields for US power projection in support of regional conflicts or humanitarian operations. For expeditionary operations, Air Force RED HORSE squadrons, Air Mobility Operations Groups, Tanker Airlift Control Elements, Contingency Response Groups (CRG), and special operations Special Tactics Teams (STT) are complementary units also certified to conduct airfield surveys, assessments, and evaluations depending on the circumstances, environment, or other mission requirements. ${ }^{44}$ These units also operate in permissive environments. The process to evaluate an airfield and assess suitability for air operations is outlined below in Figure 6.

Define Airfield Layout

Define Features

Pavement Type, Thickness, Use

Traffic Type

Soil Layers

Determine Test Locations

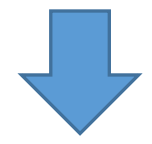




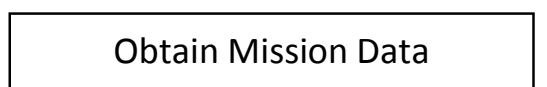

Aircraft Types/Load Data

Traffic Volume Ground Operations

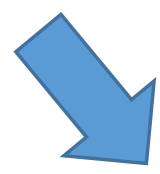

Perform Field Tests

Core Pavement

Pavement Type/Thickness

Visually Classify Soils

Determine Soil Layers

Layer Thickness/Strength

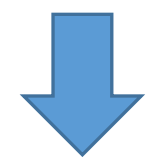

Compile Physical Property Data

Refine Features

Select Representative Profiles

Compile Physical Property Data

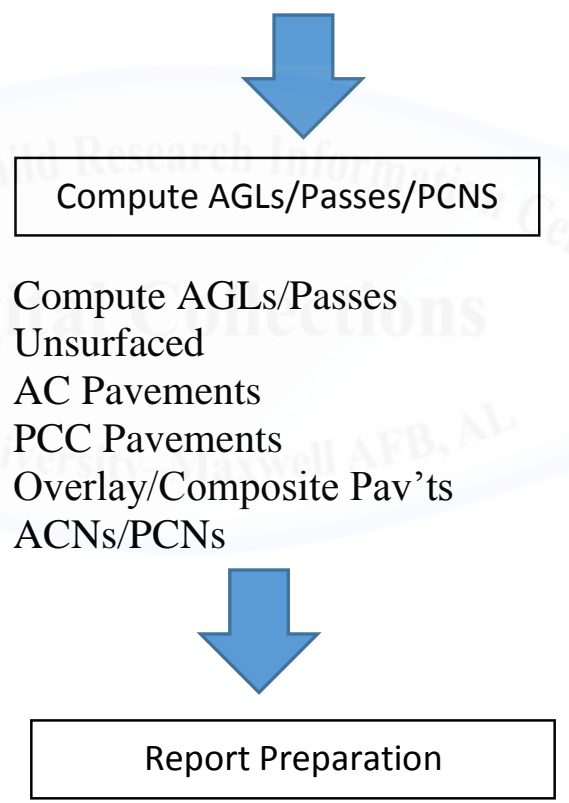

Figure 6. Airfield Evaluation Procedures

For contingency operations in a permissive environment, the CRG Airfield Assessment Team will forward deploy in preparation to establish and control air operations. ${ }^{45}$ The nine person team is led by a commissioned officer, normally an O-6, who serves as the senior airfield authority. The remaining team members include an Airfield Operations Officer and Airfield 
Manager, communications experts, logistics representatives, and security professionals. An AFOSI special agent may work with host nation security or intelligence services to assess the local threat environment. A civil engineer officer and enlisted member are responsible for performing tests of the concrete or asphalt, as well as soil samples to determine overall surface and subsurface strength and potential of airfield serviceability.

The engineer utilizes a Dynamic Cone Penetrometer and a Hilti Rotary Drill Hammer TE-56 (1100W/120V/50-60Hz) furnished with a 1 inch drill bit that is 38 inches in length. Rated speed is around 11 inches per minute, although drilling through concrete or reinforced materials may take longer than advertised. ${ }^{46}$ A chief complaint is that the engineering testing process is "slow, and low tech." 47 The team is expected to complete the initial airfield survey within four hours, and be ready to receive aircraft within 24 hours.

\section{Other Constraints}

There are a limited number of available US airfield survey teams. Additionally, the associated cost of transporting multiple teams to conduct airfield surveys is a concern to air planners. AMCI 10-202V4 acknowledges that "airfield surveys can be very costly in terms of funding and manpower."48 Furthermore, although AFI 11-235, FARP Operations, specifies an Air Force STT or HQ Air Mobility Command team would conduct the FARP survey, these high demand, low density teams may be presented with a wide spectrum of operational situations that require their specialized skill sets, or prevent their deployment in an A2/AD environment. Additionally, there are situations where team members cannot perform a quality survey due to restrictions imposed by local authorities, especially foreign governments. 
Prior to Operation IRAQI FREEDOM, the US Air Force significantly invested in air bases in Turkey. More than $\$ 7$ million was spent to upgrade key elements of infrastructure, but moreover in an attempt to help influence a change in Turkish political policy concerning air operations into Iraq. Even with millions invested, the Turkish parliament refused to permit staging in Turkey for operations into Iraq. The Turkish decision denied the Air Force two wings of air assets, including fighters and tankers, which had previously been earmarked for

employment in northern Iraq. ${ }^{49}$ In addition, carrier-based aircrews in the eastern Mediterranean found themselves in a position where Turkey's denial of the use of its airspace complicated matters further by limiting their ability to strike targets from the sea. ${ }^{50}$ Faced with these constraints, the Air Force should pursue a technology-based alternative to find and survey suitable FARP locations in contested environments.

\section{Opportunities for Technological Investment}

An optimized Rapid Raptor concept to conduct an improvised airfield survey should consist of a remotely piloted vehicle equipped with a mobile analytical survey lab similar to the scientific capabilities found on a NASA space rover. For example, the NASA rover Curiosity that deployed to Mars in 2012 is equipped with a laboratory that includes the Sample Analysis at Mars suite and the Chemistry and Mineralogy instrument. ${ }^{51}$ The Curiosity holds ten instruments weighing 165 pounds in a package that is under 10 feet in length. NASA invested $\$ 2.5$ billion total in the program, including almost two billion in research and development. ${ }^{52}$ Similarly capable scientific instruments furnished on a RSSAV, which would be comparable in size to a Predator drone, can analyze surface material and determine suitability for air operations. 


\section{Curiosity Rover (Mars Science Lab)}

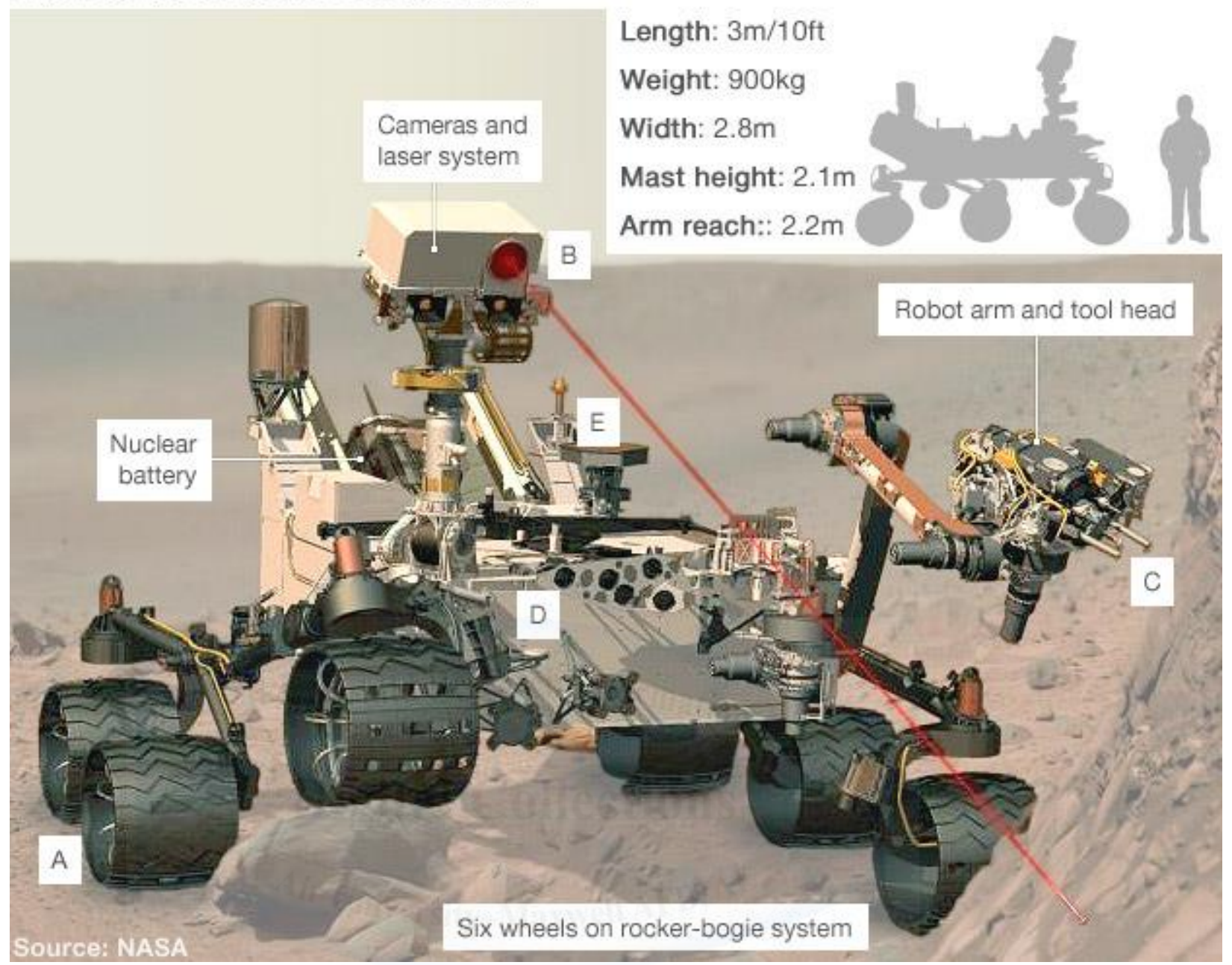

Figure 7: NASA Mars Rover Curiosity ${ }^{53}$

Another scientific instrument on the RSSAV would be the Electronic Cone Penetrometer, which would hydraulically penetrate through the concrete or asphalt, as well as the underlying soil layers 5 to $7 \mathrm{ft}$ into the earth. A data-linked computer would measure the cone tip and sleeve pressure readings, and the information obtained would be correlated to California Bearing Ratio value to determine the empirical measure of soil strength.

When outfitted with the appropriate optical sensor, the RSSAV can search for obstacles and assess if the terrain is free of hazards. With the addition of a laser, similar to what is equipped on Explosive Ordinance Demolition robots to detonate small bombs, the RSSAV may 
be able to neutralize certain sized obstacles that could have otherwise prevented using the site as a FARP. The laser can also be used as a means to provide site security. Deliverable and recoverable by air, land, or sea, the lab capabilities on the RSSAV further provide options to data link the results of soil and terrain analysis to the associated Air Operations Center to inform decision makers that the improvised dispersal airfield is suitable as a potential fighter FARP location.

The NASA rover-type RSSAV analytical survey lab can further complicate Chinese targeting by expanding the number of potential FARP sites. With the ability to conduct expeditionary surveys on serviceable terrain other than the approximately 250 established civilian airfields, the potential number of possible FARP sites can be expanded to highways and other roadways meeting the length, width, and Pavement Classification Number density classifications. When operating in swarms or 2-4 platforms, partnering RSSAVs can establish road blocks and divert traffic at the FARP location to further enhance site security and minimize the potential for aircraft and automobile accidents or incidents. The RSSAVs' operating range can be expanded through the ability to deliver it from the air, on the ground, or by sea.

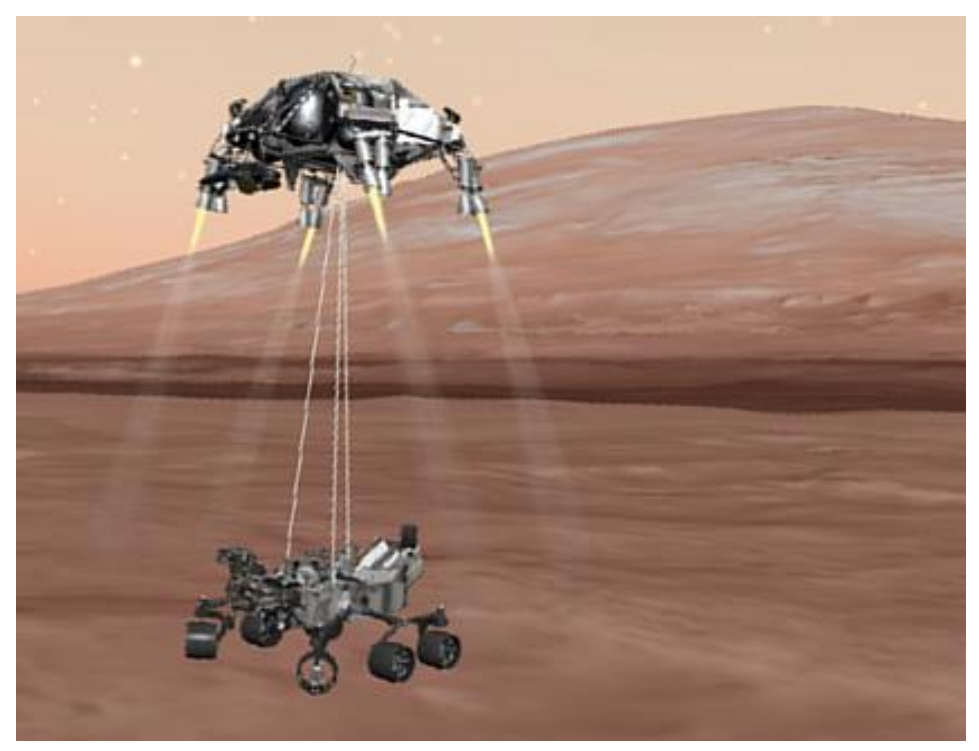

Figure 8. NASA designed the Curiosity to be air deliverable and transportable. ${ }^{54}$ Incorporating the air and ground components into a single platform is an engineering option for the RSSAV. 
At locations where the soil and terrain is suitable, yet lacks the required length or width of a hard surface, such as concrete or asphalt, the RSSAV could dispense quick drying epoxyresin to fill in craters, or 3D print tiles of airfield matting meeting the specifications required for fighter aircraft take-offs and landings. The Air Force and Marine Corps have used expeditionary airfield matting since World War Two, and it is a proven capability for fighter aircraft to successfully take off and land at improvised FARP sites. When no longer needed at a specific location, the matting can be recovered and relocated to another FARP location. Of note, dispersed airfield surface areas that are both hard and smooth are required for fighter takeoffs due to the extremely high tire pressure ratings and light landing gear struts found on many fighter jets. $^{55}$

The RSSAV overcomes the FARP survey and assessment capability gap for contested environments. In effect, the RSSAV can be equipped to accomplish each role of a traditional human airfield assessment team restricted to operating in permissive environments. ${ }^{56}$ As such, the RSSAV not only solves the survey capability limitation, it also eliminates risk to the assessment teams and the teams operating delivery vehicles. In this light, the RSSAV concept to optimize airfield survey teams while reducing the risk to Air Force personnel is consistent with Gen Hap Arnold's foresight towards seeking an alternative to fighting wars with people. Gen Arnold said, "It is a fundamental principle of democracy that personnel casualties are distasteful. We will continue to fight mechanical rather than manpower wars."57 However, this concept is more than simply adding a new gadget or platform to the military inventory.

It is in the application of the technology within the concept, and combining it with other systems within available systems, where power projection can be elevated. According to Max Boot, "The key to success is not just inventing or buying a new technology, but also in how you 
harness it." Boot continued, an example is in how Germany integrated the technological advances in tanks, aircraft, and communications, and invented the blitzkrieg, a new way of mechanized warfare that "revolutionized war in the twentieth century." 58 France and Britain also had similar military tools, yet failed to transform their militaries and strategies in ways comparable to the Germans. The incorporation of a RSSAV in support of air missions to locate improvised dispersal airfield locations optimizes the Air Force's ability to project power in highly contested environments.

\section{Evaluating the Potential of Asian Highways as Improvised Dispersal Airfields}

Improvements in transportation infrastructure throughout Asia offer exploitable opportunities to use sections of highways as improvised airfields. While not all roads in Asia would be suitable for improvised airfields, an Asian Development Bank research study identified over 140,000 kilometers $(\mathrm{km})$ of roads that meet the standard as "Asian Highways" per the criteria referenced in Table 1. Of note, dispersed air operations using highways would require sections of suitable surface areas that are approximately $8,000 \mathrm{ft}$ or $2.4 \mathrm{~km}$ in length. Of the $140,000 \mathrm{~km}$, about $106,000 \mathrm{~km}$ are located in developing member countries. ${ }^{59}$ With individual road lane widths averaging $12 \mathrm{ft}$, multiple-lane highways in design category type Primary, Class I, and Class II would likely meet the minimum width requirements of $75 \mathrm{ft}$ for fighter operations.

Table 1: Summary of Asian Highway Design Standards

\begin{tabular}{|c|c|c|c|}
\hline Type & Number of Lanes & $\begin{array}{c}\text { Width of Lanes } \\
\text { (Meters) }\end{array}$ & Pavement Type \\
\hline PRIMARY & 4 or more & 3.50 & Asphalt/cement concrete \\
\hline CLASS I & 4 or more & 3.50 & Asphalt/cement concrete \\
\hline
\end{tabular}




\begin{tabular}{|c|c|c|c|}
\hline CLASS II & 2 & 3.50 & Asphalt/cement concrete \\
\hline CLASS III & 2 & $3.00-3.25$ & Double bituminous treatment \\
\hline
\end{tabular}

Note: Primary class refers to access controlled highways (used exclusively by automobiles). ${ }^{60}$

Dispersal operations from highways also facilitate logistical support. When C-17 airlift is unavailable, petroleum, oil, and lubricants, as well as munitions could be delivered by sea and transported via convoy from designated areas. If necessary, US intelligence operatives or special operations forces could coordinate with trusted local agents to move the required logistical items to designated areas. Optimizing logistic and security support as part of this concept are areas where additional research is necessary.

Continued investments in road infrastructure are projected in the near and long term, as there is a key linkage between continued investments in highways to a stronger Asian economy. ${ }^{61}$ Specifically, the Asian manufacturing sector is reliant on efficient and reliable roads between ports, factories, and consumer markets. The road linkage between production to distribution locations enhances the movement of marketplace goods, services, and people throughout Asia, and contributes to increased transactions across borders.

Continued economic progress throughout Asia is linked to a modernized highway infrastructure. As such, the availability of suitable surface materials throughout Asia for dispersal airfields will increase by 2040. According to the Wall Street Journal, expressways in China alone total 46,000 miles $(74,000 \mathrm{~km})$, approximately the same amount of miles as found in the US interstate system. ${ }^{62}$ China's Ministry of Transport forecasts that by 2020 , China will have $85,000 \mathrm{~km}$ of national expressways. Air planners would be well served to exploit this opportunity and use these improved roads as dispersal airfields in order to project power in highly contested environments. 


\section{Humanitarian Power Projection in Highly-Contested Environments}

The US military will continue to enable the projection of diplomatic or economic power in highly contested humanitarian situations. In response to natural disasters, crises derived from internal conflict, or regional instability, the US military has an expanding role in humanitarian aid assistance. Operations in Kosovo, Haiti, Africa, Northern Iraq, and Japan are recent examples where US airpower has been called upon to support those in need. In certain situations, politically contested airspace, geography, security threats, or damage to existing runways may limit options for where US aircraft can take-off and land.

Highly contested humanitarian environments may include the US or foreign Governments narrowly defined political boundaries by which US military forces may be employed, to include restrictions on size, scope, duration, equipment, or force structure. A RSSAV used to conduct airfield suitability surveys and assessments to locate alternative and improvised landing fields during a humanitarian crisis or natural disaster would afford increased opportunities to provide supplies and other resources if established airfields become unusable or are politically sensitive.

Additionally, the RSSAV's multirole scientific instruments can optimize humanitarian missions or US Government outreach partnership to build cultural ties. Potential operations include securing agricultural areas and enabling local farmers to grow crops. These operations may be part of long-term stability programs, post armed conflict, or following a natural disaster. The US Army recognizes that the "agricultural sector is a cornerstone of a viable market economy," and that "providing crops and livestock is vital to local markets and international 
trade." 63 It dedicates a chapter in the field manual on stability operations to provide context to an issue operational planners may encounter in the future.

In Afghanistan, the US military supported a Government-sponsored initiative to replace poppy bulbs, the central component in opium, with an alternative crop. If executed smartly, the crop substitution was intended to undermine a key Taliban funding avenue, and provide stable jobs to local farmers. In turn, the effort would provide an economic boost to communities as supporting infrastructure developed. "The farmers don't get rich on poppy," said Gen Stanley McChrystal, who commanded coalition forces in Afghanistan during 2009. "If you can protect the farmer and give him the ability to get to market he's going to do fine with other crops." 64 Outfitting the RSSAV with sensors and other capabilities to assist in agricultural efforts during stability operations enhances this concept through development of a multirole platform, and further optimizes power projection.

Unmanned aerial systems are currently used by farmers to conduct assessments of crop and agricultural lands. These low-cost remotely piloted vehicles can be programmed to hover or fly over fields and data link digital videos or photos to a location on the ground, where the images can be sequenced together to show terrain features or analyzed to measure crop health. The drone vehicles can also be modified to land and take soil and water samples. ${ }^{65}$ Christopher Doering from the USA Today reported the price tag on agricultural drones range in cost from $\$ 2,000$ for a platform that an individual farmer can assemble to around $\$ 160,000$ for a militarystyle remotely controlled vehicle equipped with infrared cameras, sensors, and other technology. ${ }^{66}$

Available sensors can include Laser Illuminated Detection and Ranging (LIDAR), which can penetrate through vegetation and is useful in 3D digital surface modeling, as well as 
detecting variations on the surface. ${ }^{67}$ For example, HoneyComb, an Oregon-based manufacturer of remotely piloted vehicles, constructs a comprehensive drone platform that can be outfitted with a myriad of sensors, to include thermal imaging, stereoscopic and multispectral Normalized Difference Vegetation Index, with a battery life of approximately one hour, and at a cost of less than $\$ 15,000$ USD. $^{68}$ An RSSAV outfitted with multipurpose scientific instruments can have a huge impact on building cultural ties between the US and key partner nations.

\section{Opportunities for Deception Operations}

Deception operations are a cornerstone of military strategy. ${ }^{69}$ The Luftwaffe dedicated significant attention to airfield attacks during the Battle of Britain. As part of their airbase defense strategy, the Royal Air Force constructed decoy bases near their main operating bases. Initially using little more than lamps to suggest airfield markers, the decoy initiative later incorporated moving damaged airplanes to the decoy fields so German battle damage assessments would report successful strikes. In all, the Germans conducted over 440 raids against the dummy airfields, as compared to approximately 430 strikes targeting operational units. $^{70}$

In a modern era where electronic signatures can be intercepted and platform type and locations identified through the electronic spectrum, another mission for RSSAV could be to maneuver to dispersal locations in order to broadcast the electronic characteristics of a more valuable aircraft, such as the F-22. Flooding the electronic airways across an area of operation with what appears to be swarms of fighter jets would further confuse C4ISR capabilities, complicate adversary targeting, and promote aircraft survivability. The success of decoy airfields during the Battle of Britain highlight opportunities for deception operations utilizing 
swarms of remotely piloted vehicles in support of air missions at improvised dispersal airfield locations. This concept adds value to the discussion on identifying ways to increase aircraft survivability.

\section{Conclusions}

In summary, this paper discussed an overview of the strategic problems air planners encounter when evaluating ways to project power in highly contested environments, and outlined the operational challenges concerning air operations over extended distances from main staging bases outside the probable mission area. Examples in wars since World War Two illustrate how sustaining sortie generation from main operating bases to locations over extended distance presents certain operational risk due to the amount of flying time required from takeoff to landing, as well as the possibility of pilot fatigue over time. Further, massing aircraft at a main operating base has strategic risk as air planners such as Gen Douhet assess targeting airfields as the easiest and most efficient way to destroy an enemy's air capabilities.

An alternative is to disperse air operations, which affords certain advantages; however, the Air Force has limited capability to conduct airfield surveys outside of a permissive environment. Optimizing the Rapid Raptor FARP concept is necessary to avoid a scenario limited by operating from civilian airbases, locations well known to the enemy. If the enemy can find US aircraft, those platforms are inside the enemy's kill chain. Conversely, dispersed FARP sites using suitable highways and other roads disrupts the enemy's kill chain as the enemy is unaware where air operations are generated. With more than $140,000 \mathrm{~km}$ of roadways in the Pacific, there are suitable surface areas that meet the 8,000 ft length and $75 \mathrm{ft}$ width requirements 
for air operations. Conducting air operations from improvised dispersal sites would further complicate an adversary's ability to find and target US aircraft.

Investments in a low cost remotely operated vehicle, outfitted with scientific and other instruments capable of conducting surveys and assessments of potential improvised FARPs, offers multiple advantages to a US air strategy of dispersing airfield operations and aircraft staging in a contested environment. A technological solution for investment consideration is the multipurpose RSSAV. The RSSAV equipped with various sensors overcomes the human FARP survey and assessment capability gap for contested environments. In effect, the RSSAV can be equipped to accomplish each role of a traditional human airfield assessment team restricted to operating in permissive environments. Building on the $\$ 2.5$ billion NASA invested in research and development of the Curiosity space analytic lab, the Air Force can find efficiencies in operationalizing the RSSAV concept. If America can conduct assessments and report scientific analysis of soil on Mars, certainly conducting similar operations on Earth are possible. ${ }^{71}$

The 2015 US National Security Strategy outlines a requirement to have the capabilities to assure access to the arteries of the global shared spaces, or global common areas. ${ }^{72}$ In doing so, the US assumes a leading role in enabling the free flow of people, goods, services, and ideas that serve as the cornerstone to the security of a global economy and civil society. Innovative military solutions to address and overcome these challenges are needed, especially as strategists explore alternative options to conducting air operations from main operating bases over extended distance. The ability to conduct air operations from dispersed locations closer to a potential adversary or humanitarian situation, while complicating an adversary's ability to find and target one's own aircraft during a conflict, is a critical enabler in the Air Force's ability to project power by 2040 . 


\section{APPENDIX A}

Asian Highway Sections by ADB Developing Member Country (DMC)

\begin{tabular}{|c|c|c|c|c|c|c|c|}
\hline ADB DMC & Primary & $\begin{array}{c}\text { Class } \\
\text { I }\end{array}$ & $\begin{array}{c}\text { Class } \\
\text { II }\end{array}$ & Class III & Below III & Other & $\begin{array}{l}\text { Total } \\
(\mathrm{KM})\end{array}$ \\
\hline Afghanistan & - & - & 621 & 77 & 3,549 & - & 4,247 \\
\hline Armenia & - & 142 & 377 & 479 & - & - & 998 \\
\hline Azerbaijan & - & 82 & 1,012 & 348 & - & 228 & 1,670 \\
\hline Bangladesh & - & 20 & 441 & 476 & 868 & - & 1,805 \\
\hline Bhutan & - & - & 6 & - & 161 & - & 167 \\
\hline Cambodia & - & - & 398 & 743 & 199 & - & 1,340 \\
\hline$* \mathrm{PRC}$ & 4,140 & 189 & 2,749 & 2,008 & 1,443 & 15,400 & 25,929 \\
\hline Georgia & - & 8 & 788 & 358 & - & - & 1,154 \\
\hline India & - & 484 & - & 10,869 & 105 & - & 11,458 \\
\hline Indonesia & 335 & 18 & 1,600 & 1,965 & - & 34 & 3,952 \\
\hline Kazakhstan & - & 72 & 767 & 10,004 & 2,364 & - & 13,207 \\
\hline Kyrgyzstan & - & - & 464 & 511 & 720 & - & 1,695 \\
\hline$*$ Lao PDR & - & - & - & 2,375 & - & 3 & 2,378 \\
\hline Malaysia & 795 & 67 & 733 & - & - & - & 1,595 \\
\hline Mongolia & - & - & 440 & 345 & 3,501 & - & 4,286 \\
\hline Myanmar & - & 147 & 144 & 983 & 1,729 & - & 3,003 \\
\hline Nepal & - & - & 311 & 1,003 & 12 & - & 1,326 \\
\hline
\end{tabular}




\begin{tabular}{|c|c|c|c|c|c|c|c|}
\hline Pakistan & 358 & 1,116 & 160 & 2,569 & 1,172 & - & 5,377 \\
\hline Philippines & - & 17 & 27 & 2,872 & 451 & 150 & 3,517 \\
\hline Republic of & 466 & 197 & 244 & - & - & - & 907 \\
Korea & & & & & & & \\
\hline Sri Lanka & - & - & 269 & 190 & 191 & - & 650 \\
\hline Tajikistan & - & - & 289 & 603 & 1,033 & - & 1,925 \\
\hline Thailand & 182 & 2,572 & 1,226 & 1,128 & - & 4 & 5,112 \\
\hline Turkmenistan & - & - & - & 2,180 & 24 & - & 2,204 \\
\hline Uzbekistan & - & 255 & 765 & 1,618 & 328 & - & 2,204 \\
\hline Viet Nam & - & 408 & 1,915 & 104 & 251 & - & 2,678 \\
\hline TOTAL & $\mathbf{6 , 2 7 6}$ & $\mathbf{5 , 7 9 4}$ & $\mathbf{1 5 , 7 9 4}$ & $\mathbf{4 3 , 8 0 8}$ & $\mathbf{1 8 , 1 0 3}$ & $\mathbf{1 5 , 8 1 9}$ & $\mathbf{1 0 5 , 5 4 6}$ \\
\hline
\end{tabular}

\section{Notes}

(All notes appear in shortened form. For full details, see the appropriate entry in the bibliography)

${ }^{1}$ Conrad C. Crane states in his book, American Airpower Strategy in Korea, 1950-1953, that Air Force Office of Special Investigations special agent Donald Nichols provided the initial notification to the Commander, Far East Air Forces, that the North Korean military had invaded the South, 52.

${ }^{2}$ Runway length and width requirements for specific airframes are outlined in 11 series Air Force Instructions (AFIs) that cover flying operations.

${ }^{3}$ While multiple Air Force documents address the requirements to conduct assessments and surveys of expeditionary airfields, Engineering Technical Letter 02-19: Airfield Pavement Evaluation Standards and Procedures, 12 November 2002, provides a general overview of the process.

${ }^{4}$ Joint Operational Access Concept, January 2012, ii.

5 The Economist, The Fourth Modernization, 2 December 2010. http://www.economist.com/node/17601487/

${ }^{6}$ Office of the Secretary of Defense, Annual Report to Congress: Military and Security Developments Involving the People's Republic of China 2014, 27.

7 The Economist, The Fourth Modernization, 2 December 2010. http://www.economist.com/node/17601487/

${ }^{8}$ Report to Congress, 43.

${ }^{9}$ The Economist, The Fourth Modernization, 2 December 2010. http://www.economist.com/node/17601487/

${ }^{10}$ John Halliday, Tactical Dispersion of Fighter Aircraft: Risk, Uncertainty, and Policy Recommendations, RAND, February 1987, 13. 
${ }^{11}$ Peng Guangqian and Yao Youzhi, ed. The Science of Military Strategy, Military Science Publishing House, Academy of Military Science of the People's Liberation Army, Beijing, 2005, 300.

${ }^{12}$ John Stillion and David T. Orletsky, Airbase Vulnerability to Conventional Cruise-Missile and Ballistic-Missile Attacks: Technology, Scenarios, and U.S. Air Force Responses, RAND Corporation, 1999, 54-55.

http://www.rand.org/pubs/monograph_reports/MR1028.html

${ }^{13}$ Benjamin S. Lambeth, The Unseen War: Allied Air Power and the Takedown of Saddam Hussein, 93.

${ }^{14}$ As referenced in John A. Olsen's A History of Air Warfare, 272.

${ }^{15}$ Ibid., 272.

${ }^{16}$ Marshall Michel II, The 11 Days of Christmas, 78.

${ }^{17}$ Christopher M. Centner, "Ignorance is Risk: The Big Lesson From Desert Storm Air Base Attacks," Airpower Journal, Winter 1992. http://www.airpower.maxwell.af.mil/airchronicles/apj/apj92/win92/centner.htm

${ }^{18}$ Lambeth, 23.

${ }^{19}$ Ibid., 84.

${ }^{20}$ Michel, 75.

${ }^{21}$ As quoted in P.W. Singer, Wired for War, The Robotics Revolution and Conflict in the $21^{\text {st }}$ Century, 202.

${ }^{22}$ Giulio Douhet. The Command of the Air, 53-54.

${ }^{23}$ Halliday, 12.

${ }^{24}$ Christopher M. Centner, "Ignorance is Risk: The Big Lesson From Desert Storm Air Base Attacks", Airpower Journal, Winter 1992. http://www.airpower.maxwell.af.mil/airchronicles/apj/apj92/win92/centner.htm

${ }^{25}$ Mark Clodfelter, Beneficial Bombing, The Progressive Foundations of American Air Power, 1917-1945, 95.

${ }^{26}$ Tami Davis Biddle, Rhetoric and Reality in Air Warfare: The Evolution of British and American Ideas About Strategic Bombing, 1914-1945, 248.

${ }^{27}$ Robert Pape, Beyond Strategic Bombing, 317.

28 Tyler Rogoway, Blog: Watch These MiG-29s and Su-25s Blast Off From A Highway in Belarus, 3 January 2015. http://foxtrotalpha.jalopnik.com/watch-these-mig-29s-and-su-25s-blast-off-from-a-highway-1677293059

${ }^{29}$ Katie Hunt, Fighter Jets Land on Highway as Taiwan War Games Begin, CNN, 16 September 2014. http://www.cnn.com/2014/09/16/world/asia/taiwan-jet-fighters-freeway/

${ }^{30}$ Ibid, J. Michael Cole is a correspondent for IHS Jane's Defense Weekly and a fellow of the China Policy Institute at the University of Nottingham in the UK.

${ }^{31} \mathrm{http}: / /$ foxtrotalpha.jalopnik.com/watch-these-mig-29s-and-su-25s-blast-off-from-a-highway-1677293059

${ }^{32} \mathrm{http}$ ://www.x-plane.org/home/urf/aviation/text/bas/dispersed basing.html

${ }^{33}$ Katie Hunt, Fighter Jets Land on Highway as Taiwan War Games Begin, CNN, 16 September 2014. http://www.cnn.com/2014/09/16/world/asia/taiwan-jet-fighters-freeway/

${ }^{34}$ SSgt Blake Mize, Rapid Raptor: Getting Fighters to the Fight, Joint Base Elmendorf-Richardson Public Affairs article, 20 February 2014. http://www.pacaf.af.mil/news/story.asp?id=123400928

${ }^{35}$ See Lt Col Robert Davis, Fighter FARP: An Affordable and Feasible Concept for Power Projection in an A2/AD Environment, 14 February 2014. Lt Col Davis specifies the Rapid Raptor concept uses "existing airfields throughout an area of responsibility to increase the range and tempo of fighter operations," 5. [emphasis added]

${ }^{36}$ In his February 2014 Air War College paper on Rapid Raptor, Lt Col Robert Davis identifies between 163 and 258 potential FARP airfields in the West Pacific Theater of Operations (WPTO) that meet the minimum requirements for fighter runway length and width, 35.

${ }^{37}$ Brian Everstine, "USAF Pilots Develop F-22 'Rapid' Deployment," 2 November 2013, DefenseNews, http://archive.defensenews.com/article/20131102/DEFREG02/311020005/USAF-Pilots-Develop-F-22-Rapid-

Deployment

${ }^{38}$ Adm. Jonathan Greenert and Gen. Mark Welsh. "Breaking the Kill Chain: How to keep America in the game when our enemies are trying to shut us out." Foreign Policy, 17 May 2013.

http://foreignpolicy.com/2013/05/17/breaking-the-kill-chain/

${ }^{39}$ John A. Olsen, A History of Air Warfare, 272.

${ }^{40}$ Office of the Secretary of Defense, Annual Report to Congress: Military and Security Developments Involving the People's Republic of China 2013, 68. www.defense.gov/pubs/2013_China_Report_FINAL.pdf

${ }^{41}$ While Lt Col Davis acknowledges that a FARP survey is necessary to certify any of the roughly 250 potential FAPR sites as suitable, he does not address the Air Force or military's capacity or means to conduct a survey of the FARP airfield to ensure serviceability. See endnote 19, page 35. 
${ }^{42}$ Office of the Secretary of Defense, Annual Report to Congress: Military and Security Developments Involving the People's Republic of China 2013, 81.

${ }^{43}$ Mission Brief, Air Mobility Command Contingency Response Wing, obtained by the author, January 2015.

${ }^{44}$ Engineering Technical Letter 02-19: Airfield Pavement Evaluation Standards and Procedures, 12 November 2002.

${ }^{45}$ A description of the Air Mobility Command Airfield Assessment Team was outlined during an interview with Maj Robert Arnett on 19 February 2015. Maj Arnett previously deployed as the Contingency Response Group element commander and has conducted nine "real world" airfield surveys in the CENTCOM area of responsibility.

${ }^{46}$ Email from HQ PACAF/A7NI, 19 February 2015.

${ }^{47}$ Interview with Maj Arnett, 19 February 2015.

${ }^{48}$ AMCI 10-202V4, Expeditionary Air Mobility Support Operation, 89.

${ }^{49}$ Lambeth, 42.

${ }^{50}$ Ibid., 55.

51 "Mars Science Laboratory/Curiosity," NASA Mission Profile, (accessed on 14 November 2014)

http://solarsystem.nasa.gov/missions/profile.cfm?InFlight=1\&MCode=MarsSciLab\&Display=ReadMore

${ }^{52}$ Collaboration with NASA will enable the Air Force to maximize development and implementation cost savings if a remotely piloted vehicle to conduct improvised dispersal airfield assessments and surveys

${ }^{53} \mathrm{http} / / / \mathrm{www} \cdot \mathrm{bbc} . c 0 m /$ news/science-environment-19144464

${ }^{54} \mathrm{http} / / / \mathrm{www}$.universetoday.com/100583/how-mars-failures-helped-the-curiosity-rover-land/

${ }^{55}$ Halliday, 20.

${ }^{56}$ Interview with Maj Arnett, 15 February 2015.

${ }^{57}$ As quoted in Beneficial Bombing: The Progressive Foundations of American Air Power, 1917-1945, 235.

${ }^{58}$ As quoted in Wired for War, 183.

${ }^{59}$ The Asian Developmental Bank identifies Afghanistan, Azerbaijan, Bhutan, Cambodia, People's Republic of China, Georgia, India, Japan, Kyrgyz Republic, Mongolia, Myanmar, Pakistan, Republic of Korea, Sri Lanka, Tajikistan, Thailand, Uzbekistan, and Viet Nam as developing member countries.

${ }^{60}$ Srinivasa Madhur, Ganeshan Wignaraja, and Peter Darjes, Roads for Asian Integration: Measuring ADB's

Contribution to the Asian Highway Network, November 2009, 6, http://www.aric.adb.org/pdf/workingpaper/WP37_Roads_for_Asian_Integration.pdf

${ }^{61}$ Ibid, 5.

62 "Road-Building Rage to Leave US In Dust", Wall Street Journal Online, 18 January 2011. http://blogs.wsj.com/chinarealtime/2011/01/18/road-building-rage-to-leave-us-in-dust/?mod=djemChinaRTR $\mathrm{h}$

${ }_{63}^{63}$ Field Manuel (FM) 3-07, Stability Operations, 6 October 2008, 3-17.

${ }^{64}$ Yochi J. Dreazen, "US Seeds New Crops to Supplant Afghan Poppies," The Wall Street Journal, 14 August 2009. http://www.wsj.com/articles/SB125021357982431177

${ }^{65}$ Chad Garland, "Drones may provide big lift to agriculture when FAA allows their use," Los Angeles Times, 13 September 2014. http://www.latimes.com/business/la-fi-drones-agriculture-20140913-story.html\#page=1

${ }^{66}$ Christopher Doering, "Growing Use of Drones Poised to Transform Agriculture," USA Today, 23 March 2014. http://www.usatoday.com/story/money/business/2014/03/23/drones-agriculture-growth/6665561/

${ }^{67}$ http://precisionhawk.com/

${ }_{68}$ Andrew Amato, “The 7 Best Agricultural Drones on the Market Today,” Dronelife.com, 2 October 2014. http://dronelife.com/2014/10/01/best-agricultural-drones-available-today/

${ }^{69}$ Sun Tzu, The Art of War, 66.

${ }^{70}$ Halliday, 14.

${ }^{71}$ In January 2012, the US Secretary of Defense issued strategic defense guidance in the document Sustaining US Global Leadership: Priorities for $21^{\text {st }}$ Century Defense, encouraging innovative concepts of operation to ensure the US, its partners, and allies are capable of meeting operating requirements in contested environments. It is towards this end state to which this paper seeks to contribute to the conversation on how to project power in highly contested environments.

${ }^{72}$ National Security Strategy, February 2015, 12.

${ }^{73}$ Srinivasa Madhur, Ganeshan Wignaraja, and Peter Darjes, Roads for Asian Integration: Measuring ADB 's Contribution to the Asian Highway Network, November 2009, 7 http://www.aric.adb.org/pdf/workingpaper/WP37_Roads_for_Asian_Integration.pdf 


\section{Bibliography}

Air Force Instruction (AFI) 11-235. Forward Area Refueling Point (FARP) Operations. 15 December 2000.

Amato, Andrew. "The 7 Best Agricultural Drones on the Market Today." Dronelife.com. October 2014. http://dronelife.com/2014/10/01/best-agricultural-drones-available-today/ (accessed 20 February 2015).

Biddle, Tami Davis. Rhetoric and Reality in Air Warfare. Princeton, NJ: Princeton University Press, 2002.

Centner, Christopher M. "Ignorance is Risk: The Big Lesson From Desert Storm Air Base Attacks," Airpower Journal, Winter 1992. http://www.airpower.maxwell.af.mil/airchronicles/apj/apj92/win92/centner.htm

Clausewitz, Carl von. On War. Edited and translated by Michael Howard and Peter Paret. New Jersey, Princeton University Press, 1989.

Clodfelter, Mark. Beneficial Bombing: The Progressive Foundations of American Air Power, 1917-1945. Lincoln: University of Nebraska Press, 2010.

Crane, Conrad C. American Airpower Strategy in Korea, 1950-1953. Lawrence: University Press of Kansas, 2000.

Davis, Lt Col Robert. "Fighter FARP: An Affordable and Feasible Concept for Power Projection in an A2/AD Environment." Maxwell AFB, AL: Air War College, 2014.

Doering, Christopher. "Growing Use of Drones Poised to Transform Agriculture." USA Today, 23 March 2014. http://www.usatoday.com/story/money/business/2014/03/23/drones-agriculturegrowth/6665561/

Douhet, Giulio. The Command of the Air. Translated by Dino Ferrari. Coward-McMann Inc, 1942.

Dreazen, Yochi J. "US Seeds New Crops to Supplant Afghan Poppies," The Wall Street Journal, August 2009. http://www.wsj.com/articles/SB125021357982431177

Engineering Technical Letter 02-19: Airfield Pavement Evaluation Standards and Procedures, 12 November 2002.

Everstine, Brian. "USAF Pilots Develop F-22 'Rapid' Deployment,” DefenseNews, 2 November 2013. http://archive.defensenews.com/article/20131102/DEFREG02/311020005/USAF-Pilots-DevelopF-22-Rapid-Deployment

Field Manuel (FM) 3-07. Stability Operations. 6 October 2008.

Garland, Chad. "Drones May Provide Big Lift to Agriculture when FAA Allows their Use," Los Angeles Times, 13 September 2014. http://www.latimes.com/business/la-fi-drones-agriculture-20140913story.html\#page $=1$ 
Greenert, Adm. Jonathan and Welsh, Gen Mark. "Breaking the Kill Chain: How to keep America in the Game When Our Enemies are Trying to Shut Us Out." Foreign Policy, 17 May 2013. http://foreignpolicy.com/2013/05/17/breaking-the-kill-chain/

Guangqian, Peng, and Youzhi, Yao, ed. The Science of Military Strategy, Military Science Publishing House, Academy of Military Science of the People's Liberation Army, Beijing, 2005.

Halliday, John. "Tactical Dispersion of Fighter Aircraft: Risk, Uncertainty, and Policy Recommendations.” Santa Monica, CA: RAND Corporation, 1987.

Hunt, Katie. "Fighter Jets Land on Highway as Taiwan War Games Begin." CNN, September 2014. http://www.cnn.com/2014/09/16/world/asia/taiwan-jet-fighters-freeway/

Lambeth, Benjamin. The Unseen War: Allied Air Power and the Takedown of Saddam Hussein. Annapolis, MD: Naval Institute Press, 2013.

Michel, Marshall. The 11 Days of Christmas. San Francisco, CA: Encounter Books, 2002.

Mize, SSgt. Blake. "Rapid Raptor: Getting Fighters to the Fight." Joint Base Elmendorf-Richardson Public Affairs article, 20 February 2014. http://www.pacaf.af.mil/news/story.asp?id=123400928

Obama, Barrack H. National Security Strategy. Washington, DC: The White House, February 2015.

Olsen, John. A History of Air Warfare. Washington, D.C.: Potomac, 2010.

Pape, Robert. Bombing to Win: Air Power and Coercion in War. Ithaca, NY: Cornell University Press, 1996.

Singer, P. W. Wired for War: The Robotics Revolution and Conflict in the 21st Century. New York: Penguin, 2009.

Srinivasa Madhur, Ganeshan Wignaraja, and Peter Darjes. "Roads for Asian Integration: Measuring ADB's Contribution to the Asian Highway Network," November 2009. http://www.aric.adb.org/pdf/workingpaper/WP37_Roads_for_Asian_Integration.pdf (accessed 1 March 2015).

Stillion, John and Orletsky, David T. "Airbase Vulnerability to Conventional Cruise-Missile and Ballistic-Missile Attacks: Technology, Scenarios, and U.S. Air Force Responses." Santa Monica, RAND Corporation, 1999. http://www.rand.org/pubs/monograph_reports/MR1028.html

Tzu, Sun. The Art of War. Translated by Samuel B. Griffith. Oxford: Oxford University Press, 1971.

US Department of Defense. Annual Report to Congress: Military and Security Developments involving the People's Republic of China, 2013. Washington, DC: Office of the Secretary of Defense, 2013. 
US Department of Defense. Annual Report to Congress: Military and Security Developments involving the People's Republic of China, 2014. Washington, DC: Office of the Secretary of Defense, 2014.

US Department of Defense. Joint Operational Access Concept (JOAC), Version 1.0. Washington, DC: Office of the Secretary of Defense, 2012.

US Department of Defense. Sustaining U.S. Global Leadership: Priorities for the $21^{\text {st }}$ Century Defense. Washington, DC: Office of the Secretary of Defense, 2012. 